\title{
An Update of Weavers Technical Skill and Woven Designs in South Western Nigeria
}

\author{
Emidun Olugbenga Benjamin ${ }^{1, *}$, Akinrujomu Olujoke Stella ${ }^{2}$ \\ ${ }^{1}$ Department of Industrial Design, School of Environmental Technology, Federal University of Technology, Akure, Nigeria \\ ${ }^{2}$ Department of Fine and Entrepreneurial Arts, School of Vocational and Entrepreneurial Studies, Bamidele Olumilua University of \\ Education Science and Technology, Ikere-Ekiti, Nigeria
}

Email address:

obemidun@futa.edu.ng (E. O. Benjamin)

${ }^{*}$ Corresponding author

\section{To cite this article:}

Emidun Olugbenga Benjamin, Akinrujomu Olujoke Stella. An Update of Weavers Technical Skill and Woven Designs in South Western Nigeria. American Journal of Mechanical and Industrial Engineering. Vol. 6, No. 4, 2021, pp. 43-49. doi: 10.11648/j.ajmie.20210604.11

Received: May 14, 2021; Accepted: May 29, 2021; Published: September 3, 2021

\begin{abstract}
The thrust of this paper is to assess an update of weavers' technical skills in relation to their woven designs in South-Western Nigeria. Among many traditional handcrafts that feature in Nigerian Art Industry, weaving seems to be the most prominent and the most consistent. Available loom types and accessories as observed in use in many weaving locations in South-Western Nigeria virtually possess identical structures and features. However, technical skill of weavers differs characteristically as are reflected in varied nomenclature of fabric's textural and structural patterns and designs, with weavers struggling to manipulate the 'crudity' of their tools to the technical advantage of the aesthetic appearance of woven designs. Unstructured questionnaires in Likert Scale sample was used for frequency distribution of variables, and the woven fabrics collected from the study area were subjected to visual/aesthetic description referring to appropriate circumstances surrounding production. The need to re-assess weavers' technical skill in South-Western Nigeria arises because of the changing phases of consumers aesthetic tastes and preferences, and the need to increase production at the speed commensurate to the demand of users. These need-driven values tend to generate spontaneous traditional symbolic designs and motifs suitable to re-awaken socio-cultural consciousness of consumers.
\end{abstract}

Keywords: Textural Patterns, Structural Patterns, Aesthetic Tastes, Contemporary Patterning, Aso-oke Woven Cloth

\section{Introduction}

The history of weaving in Nigeria is an expanded documentation that has generated requests for re-assessment and update, particularly the weaving industry in SouthWestern Nigeria which was boosted by the presence of the loom and the growth of cotton. (The loom is the equipment for weaving while cotton is a raw material for making yarns. $[16,8]$ stated that the English men visiting Nigeria as early as 1890 s reported that the cotton industry which spread from Nubia on the Upper Nile at the beginning of Christian era, also flourished and could favourably have been considered with those export types in Liverpool and India, while the wild silk anaphe yarn was specially prized for its special effect in woven cloth. Textiles, indeed woven pieces, were produced in Nigerian long before European contact. [4, 12,
$16,10]$ noted that there was evidence that bundled fibres were woven in Igbo-Ukwu over 1,000 years ago and later in the $13^{\text {th }}$ century. There was the Benin record the $14^{\text {th }}$ century with fabric dyeing attached to the ritual practices [15]. Although it has been acknowledged severally that the horizontal loom with treadle-operated harness was developed in Europe in the $13^{\text {th }}$ century.

Eicher, B. J. and Olutayo, A. O. had also described loom and its varieties and how they are used extensively for weaving in Nigeria $[6,16]$. The loom contains the same form of pulleys, beater and heddles and remains the apparatus that provides both for the varieties of warp threads and the means for introduction of the weft thread. It is usually supported by frames, which include provision of back and front beams. Since weaving activities provide job opportunities for the people at various levels of its production, such as planting and harvesting of cotton, spinning weaving, laundering and 
selling, the paper identifies and assesses the production quality, woven structure and tools used as they affect changes in patterns and design techniques. The paper also examines the improvement of skills and the status of Weavers contemporary knowledge of technical skill with a view to raise suggestion for its improvement. There is the need, to document and update traditional weaving processes and the skill of weaver in south-western Nigeria as regards the improvement that can provide design that will be acceptable in international market.

\section{Weavers Technical Skill and Accuracy}

The versatility and the manipulation of looms by weavers to provide traditional clothing remain the essential elements for re-assessments. It is observed that pupil weavers must have the ability to possess the speed required to complete a woven project on loom before graduation. Our discussions in this regard include how this woven accuracy can enhance effective production and design nature of woven fabrics among the pupil and master weavers. Weavers at Iseyin and Oyo achieve greater level of accuracy in weaving by a simple method of wetting the wefts. The wet wefts, when adequately sized (with starch) are used to brace-up the value of warp threads. When sundried, the heaviness required by some consumers is thus achieved. The use of multiple wefts serve as greater achievement for the accuracy. With it, a weaver may be able to complete two long lengths, which is about 20 yards in a day. There were other three major factors responsible for the influence of Weavers technical skill in the paper.

1. Warp counting and extension of heddles;

2. Manipulation of the two types of looms (horizontal and vertical) to create design for comparison;

3. Factors constituting major differences between cloths that are woven in the olden days and those made in contemporary times.

At Abeokuta and Ijebu Ode in Ogun State, weavers work in consonance with customers' orders. Unlike their counterparts in Iseyin and Oyo, Oyo State, who solicited for customers from outside the State. Generally, Lagos markets, because of their central locations remain the target of weavers for selling their woven pieces. Many who are not full time weavers combine other petty trading with a large stall for selling other types of fabrics. Sheds for the sales of woven clothes are so countless, with varieties of fabrics from other parts of Nigeria.

It is noted by $[1,13]$ that most weavers in Ekiti and Ondo states copied designs from the ones provided by consumers. Some designs that were collected from Iseyin were also seen in Ado and Akure markets. No handspun yarn was noticed as used in Ekiti and Akure zones. It was in Owo that the researcher met a handful centers where handspun yarns are being dyed in traditional methods. Modernization has compelled weavers to use factory yarns for textile production. Apart from machine cotton purchased in markets, Ekiti and Ondo weavers have been attracted to the use of fabrics synthetic fibres, including tiny shining yarns of metallic colour. This has brought profound changes in the appearance of woven cloths in Ekiti. The use of shinning yarns was said to have been adopted from various weaving sources connecting with Ekiti weavers [3, 14]. If the use of the shining thread may not attract weavers, users of handwoven cloth seem to derive satisfaction in the effects of the thread [2]. Woven cloths become lighter by it, and cloths maintain shining appearance with little or no use for laundry. The use of shining thread was later adopted by many weavers among Yoruba types of woven fabrics which have been sighted in markets in Abbomey, (Republic of Benin), and as far away as Gambia and Ghana [7, 9].

\section{Research Methodology}

The research adopts trajectory of oral research and interview to derive a rare corpus of knowledge from traditional weavers in selected weaving centers in SouthWestern Nigeria. The major information required was centered on the present state of their technical knowledge. Varied samples were identified and compared in town-bytown products of hand-woven pieces, using the criteria below:

Similar patterns (or not);

Textures are identical (or not);

Colour stripes are alike (or not);

Yarn counts are adequate for design specification (or not);

Weaving methods are similar (or not);

Loom structure and accessories are similar (or not);

Creative use of techniques;

Male and female traditional weavers must be in the category listed below before they were considered for interview:

1. Traditional Weavers age must be between 15 years and above.

2. They must be practicing weaving as occupation.

Woven samples collected from weaving centres from the four major States of Yoruba speaking people in South Western Nigeria were assembled for purpose of comparing their techniques. Data collected for the research were based on the restricted population of weavers in four states namely, Oyo, Osun, Ogun and Ekiti States and were analysed with the statistical packages for social sciences (SPSS). This assisted to state the frequency distribution responses of weavers' in these states.

The distributions of the states are shown below:

Table 1. Distributions of the states.

\begin{tabular}{lllll}
\hline \multirow{2}{*}{ State } & A & B & C & D \\
& Ekiti & Oyo & Ondo & Owo \\
\multirow{2}{*}{ Towns } & Ado & Iseyin & Ondo & Abeokuta \\
\hline
\end{tabular}

Source: Fieldwork 2020. 
A total number of fifty seven Aso oke weavers were sampled in all the four States of the study. The number constituted $10 \%$ of the total number of the weaving population in the four States. Out of the fifty seven weavers, fifteen (15), which constitutes $26.3 \%$ were sampled each in Oyo, Ogun and Ondo States while twelve, with $21.1 \%$ were interviewed in Ekiti State. This shows a total number of twenty nine male weavers of $50.9 \%$ and female weavers of twenty eight, constituting $49.1 \%$ of the total percentage of $100 \%$. The issue of gender disparities in the weaving profession in Nigeria has been addressed at various times in the works of [16] and [12] and needs not be discussed here. A greater number of women weavers were located in all the Southwestern geo-political zone except in Oyo State where only a handful off weavers were women. Weaving in Oyo and Iseyin towns is dominated by men.

Table 2. Sex of Respondents.

\begin{tabular}{llll}
\hline \multirow{2}{*}{ Sex } & Weavers & \% & \\
\cline { 2 - 4 } & Freq. & 50.9 & \\
\hline Male & 29 & 49.1 & 1 \\
Female & 28 & 100 & \\
Total & 57 & 0 & \\
\hline
\end{tabular}

Source: Fieldwork, 2020.

Table 3. Distribution of Respondents within Study Area.

\begin{tabular}{lll}
\hline \multirow{2}{*}{ Sex } & Weavers & \% \\
\cline { 2 - 3 } & Freq. & 26.3 \\
\hline Oyo & 15 & 26.3 \\
Ogun & 15 & 21.1 \\
Ekiti & 12 & 26.3 \\
Ondo & 12 & 100 \\
Total & 57 & 2 \\
\hline
\end{tabular}

Source: Fieldwork, 2020.

\subsection{Factors That Influence Changes in Structural Patterns and Designs of Aso-Oke}

The number of respondents scoring on the mean scores and ranking of the 6 leading variables responsible for the structural patterns and designs as perceived by weavers are shown in table 4 . The most outstanding of the variables which influenced structural changes was found in the weavers use and manipulation of horizontal and vertical looms. This had a mean score of 3.51. This was closely followed by the Weavers effective use of yarn counts in the formation of the heddles on the loom. Although this ranked second with a mean score of 3.18 , but the overall techniques of weaving the structural patterns rest on the use of special woven inlays introduced by the weaver. This was identified as No. 3 in the ranking with mean score of 3.04. This singular factor as a major source of cloth embellishment while weaving on the loom is shown. The impact of embroidery structure as a source of design on hand wovencloth cannot be over-emphasized. Again, consumers of handwoven cloths who constituted the third tier of the stakeholders in the assessment of structural patterns perceived that only the introduction of modem surface patterns and designs in whatever form would resolve the problem of cloth woven inlays in the production of traditional cloths.

Table 4. Weavers' Response on the Factors that Influence Changes in Structural Patterns and Designs in Aso Oke.

\begin{tabular}{|c|c|c|c|c|c|c|c|}
\hline \multirow{2}{*}{ Variables } & \multicolumn{5}{|c|}{ No. of respondents scoring } & \multirow{2}{*}{$\begin{array}{l}\text { Mean } \\
\text { score }\end{array}$} & \multirow{2}{*}{ Ranking } \\
\hline & 4 & 3 & 2 & 1 & $\mathbf{0}$ & & \\
\hline Production techniques are different from one Yoruba location to the other & 14 & 25 & 10 & 7 & 1 & 2.77 & 5 \\
\hline Special woven inlays are best as design decoration on Aso Oke & 14 & 33 & 8 & 2 & 0 & 3.04 & 3 \\
\hline Horizontal and vertical looms are used for weaving traditional cloths & 34 & 18 & 5 & 0 & 0 & 3.51 & 1 \\
\hline Horizontal and vertical looms produce identical styles of fabric & 16 & 27 & 13 & 1 & 0 & 3.02 & 4 \\
\hline Modern technology and science affect Aso Oke patterns & 8 & 20 & 18 & 2 & 8 & 2.32 & 6 \\
\hline $\begin{array}{l}\text { Lesser yarn counts and regularized materials can make Aso oke compete in } \\
\text { international market }\end{array}$ & 21 & 29 & 3 & 1 & 2 & 3.18 & 2 \\
\hline
\end{tabular}

Source: Fieldwork, 2020.

\subsection{Contemporary Knowledge of Technical Skill}

The assessment of factors influencing Weavers knowledge and technical skill was made by weavers themselves as shown in table 5. A mean score of 3.51 ranks highest on the
Table. This interpreted to mean that there was an agreement by weavers and consumers that no other type of loom could weave Aso-Oke hand woven cloth except the horizontal and vertical loom. Lack of raw materials like cotton and silk for manufacturing Aso oke affected the skills of weavers to a 
large extent. The growth of cotton for cloth manufacturing has been a bane in cloth production in recent times especially among the Yoruba of the South-Western Nigeria. Weavers' assessment of this major reason also ranked second in the Table.

There were other three major factors responsible for the influence of Weavers technical skill in the research. They are:
Warp counting and extension of heddles; Manipulation of the two types of loom to recreate designs which also necessitated the comparison accepted in research.

These factors might constitute the difference between cloth woven in the olden days and those made in contemporary times. The mean scores of 3.27, 3.04 and 3.02 represented these positions respectively.

Table 5. Assessment of ten factors that influence Contemporary knowledge of Technical skill.

\begin{tabular}{|c|c|c|c|c|c|c|c|}
\hline \multirow{2}{*}{ Variables } & \multicolumn{5}{|c|}{ No of respondents scoring } & \multirow{2}{*}{$\begin{array}{l}\text { Mean } \\
\text { Score }\end{array}$} & \multirow{2}{*}{ Ranking } \\
\hline & 4 & 3 & 2 & 1 & $\mathbf{0}$ & & \\
\hline Horizontal and vertical looms are used for weaving traditional cloths & 34 & 18 & 5 & 0 & 0 & 3.51 & 1 \\
\hline Horizontal and vertical looms can be used to produced identical style of woven fabric & 16 & 27 & 13 & 1 & 0 & 3.02 & 4 \\
\hline Modern technology affect the use of looms and other technicalities in Aso Oke & 10 & 15 & 19 & 4 & 8 & 2.27 & 10 \\
\hline Modern technology and science affect changes in Aso Oke structure & 8 & 20 & 18 & 2 & 8 & 2.32 & 9 \\
\hline Raw materials like cotton and silk are not available for manufacturing Aso Oke & 31 & 14 & 7 & 3 & 1 & 3.27 & 2 \\
\hline The use of foreign threads and yarns do not make Aso Oke suitable as traditional fabric & 10 & 14 & 28 & 2 & 2 & 2.50 & 7 \\
\hline Additional warp counts and extension of heddles can enhance production of Aso Oke & 17 & 30 & 5 & 2 & 2 & 3.04 & 3 \\
\hline The loom use in the olden days is different from the one used now & 17 & 15 & 9 & 5 & 10 & 2.43 & 8 \\
\hline The woven cloth made in the olden days is different from the one made now & 23 & 16 & 8 & 4 & 5 & 2.86 & 5 \\
\hline
\end{tabular}

Source: Fieldwork, 2020.

\section{Discussions}

Patterns of the woven fabrics in Iseyin, Oyo State are made into structural grids as calculated by weft manipulation, and according to the speed of the weaver. Designs are strictly seen on the surface of the woven fabrics and are sometimes brought by special skills in shedding devices which is controlled by the hold of shuttle and the release of the heddles at commensurate intervals. The multi-various patterns in cloths like Alaari, Sanyan, Obo, Etu, Pele, Kure and Dendelewe (miliki) indicate the versatility of weavers since each of this woven cloth, portrays different occasions which they can be used for. Alaari woven fabric is a good example. Just as Etu cloth used for wedding ceremonies, Sanyan cloth may be used for burial ceremonies. Looms in Oyo weaving centres are neat and updated and properly maintained as they are used. In addition to the general characteristics of loom equipment and materials, Oyo weavers constructed the padded seat built-in loom for comfort during the long hours of weaving. Foot loops are made flat like pedals with more elaborate heddles, beater and pulleys. The development of these loom accessories was meant to enhance high degree of performance and speed up production processes as most weavers work on commissions. Foot treadle in Oyo is enhanced with loop, which fits around the big toes of each foot of the weaver. Yarn is wound into spools by young male apprentices with bobbin made of iron revolving with the crossbars. Except special request for use of specific yarn is made, the Oyo weavers generally use factory yarns. If thick, less coarse domestic yarn is used, there will be fewer warp yarns and since most narrowband fabric is warp-faced, the overall construction of the yarns become rightly knitted.

Weavers specialize in warp-stripe pattern, which seems symmetrical or sometimes maintain asymmetrical shapes.
The shapes are repeated as weaving progresses. Occasionally, weft-shaped patterns that maintain asymmetrical patterns are monochromatic. In this regard, the manipulation of the patterns on the warp surface of the fabric encourages the use of more than one. This is seldom a special order where the patterns are used to make symbols, motifs and inscriptions of letters and words on woven fabrics.

A high standard horizontal loom is used in Ondo, Ondo State. Vertical looms are not very common at places visited but an abandoned vertical weaving centre was sited at Ododibo owned by an aged woman who claims to be specializing on Oja and Iponlerun (shoulder stands) woven cloths $\sim$ ' Cotton growing, spinning and dyeing are no longer practiced. They have been abandoned for factory spun yarns that are readily available in the market. The enhancement of weaving skills pervading in the centers also necessitated the manipulation of few cloths produced to shining colourful nature. Finished fabrics are now neatly produced and packed for sales in Akure and Ore markets.

Looms and accessories used in Ondo are of the same design with others in Yoruba towns visited, except for these few vertical looms which are either cemented on the floor at passage-lobby or stood alone in the backyard. Woven fabrics like Alaari and Etu are hand-painted with dyes when fading effects are noticed. They are then beaten and sized for future use.

Colour plays prominent role in this regard. For example, white colour is used by priests to symbolize deities and ancestral spirits. Green is worn by young girls to symbolize newness and freshness. Red is commonly used for naming and other warm ceremonies and black for death. At occasions, the Oba wears Alaari or. Sanyan, representing the dignity and loyalty of his position. Among various designs identified in Ondo woven cloth, apart from the Sanyan, Alaari and Etu are locally nick-named designs such as Lita 
(the one that has designs like pepper), Fopelo, Lalubosa (of onions), Lapola (of sticks) Lanyinyan (of images), Onjawu (of lace) Egungunelu (of a type of masquerade) Petuje, a type of Etu possesses traces of white line thread on black. Eleya is perforated type of woven cloth. Bebeidi and a layinyan both provide the display of combination of different threads in dark and red colours. Alaari cloth which is popular among the Okelisa weavers is the one with red colour stripes. Etu, which is mostly used by the older groups, is best woven at Idimoge quarters in Ondo. It is blue black in colour. Sanyan, which maintains the original colour of the fibre is a popular fabric amongst the Okedasa weavers. Fopelo, which have the combined colour of red and blue black, is as popular in Kajola quarters as others. In Owo, Ondo State, the looms are made of strong lroko (Chlorophera excellsa), Omo, (Cord millami), Ayan (Afzalia africana). TJ2Astructure of the loom requires durable woods, which can resist termite attacks and economical maintenance for many years.

Accessories such as Ogoro frond a kind of (raffia palm) is used as obiri, which separates the warp, yarns on the vertical loom. Egboro and $O f i$ are flat wood pieces constructed by a carpenter to form the entire vertical loom. This is usually 3 " by 2 " wood. Itese is a thin stick removed from palm frond to support the part of the cloth which is pressed down with the held of obiri. Apasa is a flat polished wood constructed with pointed edges. It is used as a heddle and a separator of warp yarns. Asa possesses numerous threads, which double as heddles and design motivator on the loom.

Working on a vertical loom requires more patience and calmness. In the weaving of Sewosin cloth, the weaver conceives her pattern and translates it onto egboro of $i$ i.e. the vertical loom. Two Asa (shuttles) are used to carry weft threads in and out the warping threads. Obiri and Apasa are then used to manipulate desired' designs and patterns. It is characteristic of Owo woven pieces to bear patterns of geometric shapes. Animal shapes are seldom depicted, except on request. For example, a Lizard is depicted in zig-zag geometric shape. Green and blue colours tend to activate the background of the weaves, while red lines and designs dotted the deeming background. Red colour is said to signify royalty, power and strength. Other woven fabrics in Owo bear heavy lines articulated in straight forms. Sometimes, the elaborately woven cloth bearing lighter blue and heavy white stripes are only used as Iro wrapper and shawl Iborun. Ogunduyile [5] averred that Owo woven fabric is gotten from handspun cotton coloured in blue indigo and naturally unbleached cotton. Single, two or three panel cloths such as Ikeji and Iketa are worn as shoulder cloths. A typical heavy weighted woven type known as Seghela covers heavy thick lines with deep blue colours with only counts of 10 lighter blur warps lying between. Airanlu and Olowojolaga both possesyelongated contrast of bright blue yarns. Gege pupa is entirely a red piece with horizontal and vertical lines. Cowries-like designs are woven into the structure continually, forming a diamond grid. This is achieved by shining threads.

As a "natural" center of Ekiti, Ado-Ekiti also served as provincial and zonal headquarters for colonial administration. The town attracted craftsmen and weavers who migrated from Ilorin and Iseyin. Many apprentices who learnt the art of cloth weaving in Ado later spread to many Ekiti towns and villages. [11] reported that pockets of weavers were still found in Ido-Ekiti during their fieldworks in 1978.

From the organization of the threads to warp winding, spacing the thread and tensioning warp yarns, making shedding devices and placing short shuttles, and from beating the weft to regulating selvedges, weaving in the South-West takes almost the same process. Investigation reveals that a large proportion of weavers in Ado-Ekiti today are nonindigenes. Few weavers are of Ado origin. They are located at odd places like shops and kiosks where weaving activities would seem impossible.

Traditional handspun yarns are not of common use among Ado-Ekiti weavers. This greatly affects design concepts. Commercial cone of yarns of assorted colours, (tailor's thread) are wound on plastic and wooden spools, transferred on a creel (spool rack) before used for warping. Many decorative materials are adopted for patterning on Aso oke at Ado. These include metallic type of silk yarns, lightweight shinning yarns and wood thread. Glittering woven cloth was almost the trademark of modem weaving in Ado-Ekiti at the end of the end of the 1990s. Patterning and designing processes depend solely on the skills of weavers, which is brought about by long years of contact with varied designs outside Ado-Ekiti.

An emerging design phenomenon in the woven fabric in Ido-Ekiti (another town in Ekiti State) is the use of brighter, much brighter colours against a deem background. This observation was made in special pattern of Aso oke for associations of friends of age peers for special event like "Ido-Faboro day". The imitation of geometrically drawn designs in Oyo resurfaced in Ido-Ekiti during the fieldwork. Apart from this, symbols and motifs on cloths are produced by other techniques and are given different names. Designs on calabashes and leather works of Ilorin people also appear as diagonal and zigzag or sometimes in solid triangles.

Designs in Ido-Ekiti portray their social life patterns. For example, Olopon ayo derived from popular Ayo game, Obibo, metal rods and Agbelebu, crucifix symbolizing Christianity are all adapted from Ode and Ijan weavers. Heavy patterning and designing of fabric requires additional changes while fabric produced with inferior quality of cheaper yarn possess minimum designs.

Weavers work on their looms according to request by patrons. At Ilugun-Asalu and Ijaye in Abeokuta (Ogun State), a weaver could weave up to 20 metres of stripe a day if floating or inlay designs are not requested on them. The shinning yarns, which are widespread in use among Yoruba weavers are also used to create changes with yarns that are symbolic of the modem day technological advancement. Blocks of motifs and checker effects conspicuously dominate designs from Ijaye area of Oyo State.

The overbearing thickness in Abeokuta woven cloths are embedded in inlay floats, which is used dramatically to proof 
a professional point. Weavers' exceptional capacities for juxtaposition of colours in weft threads seem to enhance the beauty of the woven cloth. The thickness, however, of woven pieces, is enveloped in pools of regulated shapes and in array of colours. With due regard to the basic principles of weaving, many collected woven pieces such as Ori merin, Ori loye, Ifuja and Alaare kekere, also showcase skillful use of assorted threads and professional manipulation of the loom to reactivate these colourful threads in visual grandeur. When compared, prices of Abeokuta woven pieces rank among the highest in Yoruba towns because of their high standards.

The Ijebu weavers seem meticulous in setting warp yarns on $100 \mathrm{~m}$ having taken cognizance of the level of the finished web, the composition of the warp yarns the length and width of the warp yarns, the sequence in which the warp yarns and thread through the heddles and the reed, weavers provided a more careful creative artistry when weft yarns are selected. In their own case, stronger weft may not be so desirable for use. It is in Ijebu Ode that the researcher got to know that the density of a planned fabric determines the size-mot thickness in this case). A tightly open web with fine yarns of course requires more warps than an open-warped fabric. When a smooth, even; tension is maintained throughout the winding process the entire woven pieces are gauged in the same strength. By this method, weavers in Ijebu were able to weave softer Etu fabrics to satisfy some customers who prefer them.

It is noteworthy that warping is wound in the same day, and at once because of the traditional methods adopted. If warping is delayed, and a time-gap created between it, the atmospheric condition seems to affect the tensioning. Tensioning, as important as it is in producing compact weaving, is a technical knowhow, which weavers administer from time to time. Bogus and elaborate figurative designs such elephant and fish motifs now appear in smaller decorative grids that tend to show the artistic aptness and accuracy in Ijebu woven fabrics. In the past, the Ijebu weavers used tortoise motifs as a sign of royalty. Agemo, a lizard-like motif is also used to honour the Ijebu festival of Agemo. The Biblical Cross and other related motifs were introduced in woven stripes as Christian religion became household affair.

When decorations are patterned in the cloths, the warped area where the decoration would be made will first be established. The area will then be separated from the main warp threads. Wooden frame of about $4 \mathrm{~cm}$ by $7 \mathrm{~cm}$ will be used to effect the $\sim$ separation while the designs are labeled ABCDE. Numbers of yarns in design could be 88,44 or 10 , depending on the size of the decoration. Objects like fish and elephant are brought out by adequate draft plan actualized through warping, and made permanent through wefting.

\section{Conclusion}

The historical development of weavers and their skills are being investigated in this research vis-a-vis the entrepreneurship. The skills of weavers were examined and suggestions about the development of skills and manipulation of materials were considered to suit the modern day consumers. The fabrics have been discussed according to nomenclatures in the environment in which they exist.

Handwoven fabric seems to be faring well among other types of handcrafted fabrics in South-Western Nigeria. The increase in demand has also necessitated weavers to multiply by the day. The study, however, identified some problems confronting the manufacturing industry and proffered solutions to them. The problems are discussed under three main headings:

1. Man power needs.

2. Material and infrastructure.

3. Standardized equipment and accessories for mass production.

\subsection{Manpower Needs}

The dearth of skilled craftsmen has affected the production of handwoven fabrics. Apprentices who are graduating from master Weavers everyday do not exercise patience for the study and manipulation of- the $100 \mathrm{~m}$ for improved design. Formal education (though a necessity in society) has relegated the craft of weaving to a part-time activity. Production process is slowed down by this. Although many full-time weavers still consider to participate in other trades that may bring quick profit. The weaving industry thus, need devoted weavers and skilled craftsmen to cater for the findings of this research.

\subsection{Aterials and Infrastructure}

The absence of handspun yarns created from raw cotton has been noted in the paper. Cotton farmers are no longer available in the South-Western Nigeria. Indigenous governments do not encourage the growth of cotton because cottage industries now prefer the use of imported brands of threads for weaving. The local breeding of silkworm to create steady materials for silk weaving cannot be ascertained. To sustain the art, weavers now rely on imported threads to create and re-create varieties of handwoven cloths which were identified as too foreign to traditional setting. Lack of infrastructure is regarded as a setback for the weaving profession. Since weaving activity is performed mostly in open space, rains and chilly weathers tend to affect weavers. Production is thus slowed down during the raining season.

Standardized Equipment and Accessories

The research suggested that faster and effective method of fabric production can be achieved when accessories and materials are available for mass production. Having examined various forms and contents of technical skill of weavers in South- Western Nigeria, the study also assessed the trends of manufacturing technology among Yoruba weavers, whose works cannot still be duplicated by factory machines. The work can still be extended in the following areas:

A comparative study of woven cloths among other ethnic groups in Nigeria and other countries can still be conducted. 
This could be in the area of technique, materials, style and cultural significance.

Further studies should be done on the care of handwoven cloths. Laundry, colour protection and durability should be ascertained in greater measure so as to ensure standard quality for consumers.

Mechanization of looms that can accommodate a wide variety of lengths and yardages of fabrics would provide good result in manufacturing area if further research is intensified.

\section{References}

[1] Amubode, A. A and Adetoro, S. A. (2001) The Use of AsoOke in Yoruba Marriage Ceremonies. The Nigerian Field, 66: 29-34. The Nigerian Field Society, Nigeria.

[2] Ademuleya, B. A. (2002) Continuing appreciation of the old aso-oke types among the Yoruba of Ondo, Unpublished Ph.D. thesis, Institute of African Studies, University of Ibadan.

[3] Adiji B. E. and Emidun O. B. (2011) Effect of Technology on Nigerian Handcrafted.

[4] Asakitipi A. O. (2007). Functions of hand-woven textiles among Yoruba. Nord. J. Afr. Stud. 16 (1): 101-115.

[5] Diogu, G. O. (2001). Patterns of creative growth in Contemporary Nigerian Textiles, Journal of creative Arts, Uniport. P/H. Vol. 1 No. 2. pg. 87.

[6] Eicher, B. J. (1976). Nigerian Handcrafted Textiles: Ile-Ife: University of Ife Press, pp 12 22; 33; 65.
[7] Newman, T. R. (2010). Contemporary African Arts and Crafts-on-site Working with Art Form and Processes. London: George Allen \& Unwin Ltd., pp 79, 102-110.

[8] Ogunduyile, S. R. and Adepeko, E. O. (2006). Nigeria Clothing Traditional: Preservation Restoration of Alaari Fabrics among the Ondo people of South-Western Nigeria. A Draft Paper.

[9] Ohiorheruan, D. O. (2002). Issues Affecting Design, Reproduction and Marketing of Nigerian Textiles. JINDEST, $2^{\text {nd }}$ Ed., Vol. 2, pp $73-75$.

[10] Ojo, E. B. (2006) An appraisal of weaving cottage industry in South-Western Nigeria, in Potentials of visual Arts and Crevity, CCAF Publication, 2006.

[11] Ojo E. B. (2007). Printing contemporary handwoven fabrics (aso-oke) in southwestern Nigeria. Design Issues 23 (2): 3139 .

[12] Okeke, C S (2005) Distinctiveness in West-African Textiles, Nigerian journal of Art vol 4 nos $1 \& 2$.

[13] Ososipe, A. Y. (2001). Narrow Band Weaving in Abeokuta South Local Government. Unpublished B.Sc. Thesis, UNAAB.

[14] Renne EP (2000). The Decline of women's weaving among the North East Yoruba. Textile History.

[15] Popoola, V. A. (2001). Textiles: Then and Now. An Inaugural Lecture Series. Nigeria: Industrial Design Department, FUTA.

[16] Olutayo, A. O., Olayinka A., Kunle and Fadina, O. O (2011): Aso-Oke (Hamd Woven Textile) of Southwestern Nigeria. A Compact Examination of Resilient Artified. American Journal of Sociological Research. 